\title{
SIMPLE EMERGENCY TRIAGE (SET) - THE NEW PERSPECCTIVE ON MASS CASUALTY INCIDENT TRIAGE
}

\author{
Jerzy Jaskuła ${ }^{1}$, Marek Siuta ${ }^{2}$
}

\author{
1 DEPARTMENT OF MEDICAL DIDACTICS, FACULTY OF MEDICINE, JAGIELLONIAN UNIVERSITY MEDICAL COLLEGE, CRACOW, \\ POLAND \\ 2 DEPARTMENT OF DISASTER MEDICINE AND EMERGENCY CARE, CHAIR OF ANESTHESIOLOGY AND INTENSIVE CARE, FACULTY \\ OF MEDICINE, JAGIELLONIAN UNIVERSITY MEDICAL COLLEGE, CRACOW, POLAND
}

\section{Abstract}

The aim: Incidents with large number of casualties present a major challenge for the emergency services. Incident witnesses are always the first on scene. Authors aim at giving them an algorithm arranging the widely known first aid rules in such way, that the number of potential fatalities before the services' arrival may be decreased.

Material and methods: The authors' main aim was creating an algorithm for mass casualty incident action, comprising elements not exceeding first aid skill level. Proceedings have been systematized, which led to creation of mass casualty incident algorithm. The analysis was based on the subject matter literature, legal acts and regulations, statistical data and author's personal experience.

Results: The analysis and synthesis of data from various sources allowed for the creation of Simple Emergency Triage (SET) algorithm. It has been proven - on theoretical level - that introducing an organized way of proceeding in mass casualty incident on the first aid level is justified.

Conclusions: The SET algorithm presented in the article is of an implemental character. It may be a supplement to basic first aid skills. Algorithm may also be the starting point for further empirical research aimed at verifying its effectiveness.

\section{Key words}

triage,

mass casualty incidents,

first aid,

medical education, cardiopulmonary resuscitation

\section{INTRODUCTION}

Action schemes used by the emergency services during a mass casualty incident significantly differ from procedures used in situations where all the necessary forces and resources are available at once. This concerns in particular the early phase of action, during which the medical segregation takes place. Giving therapeutic and transport priorities is based on one of many available triage algorithms. Legally accepted median of emergency medical team arrival on scene in Poland is 8 minutes within the city with over 10000 inhabitants and 15 minutes elsewhere [1]. In case of mechanism inflicting potentially lethal injuries, many victims will have no chance of survival after such time. This can be changed only by rapid reaction of witnesses present on scene before rescuers and emergency medical teams arrive. Current legal state in Poland does not impose the use of any particular triage system on all emergency services. The situation is most explicit among the National Firefighting Rescue System units. These are bound by the document regulating the rules of organizing emergency medical rescue within the NFRS (,Zasady organizacji ratownictwa medycznego w KSRG") acknowledged by the national chief fire officer in
July 2013. This document defines the initial and secondary segregation, and imposes the use of START / Jump-START system for the initial segregation [2]. One should take no more than 30 seconds to assess a casualty, during this time it is advised to give priority, place in a position securing airway patency and control massive external bleeding [2]. START / Jump-START is also the algorithm most widely known among the emergency medical teams of the state emergency medical system. These however are not obliged by any regulation to use this particular algorithm. START / Jump-START system was created in the 1983 in Hoag Hospital System and Newport Beach (CA) Fire Department [3]. One of its arguable presuppositions was it being useful for the individuals with no medical background (despite the proper assessment of radial pulse necessary for completing the procedure).

In 2015 the guidelines concerning mass casualty incident procedures were published by the national consultant in emergency medicine (,Zalecenia konsultanta krajowego w dziedzinie medycyny ratunkowej dotyczące procedur postępowania na wypadek wystąpienia zdarzenia mnogiego/masowego"). This document does not impose any particular triage sys- 
tem on the members of emergency medical teams. It does however repeatedly refer to giving casualties one of four priorities, compliant with START / Jump-START algorithm [4]. The widely accepted use of this system makes it easier to cooperate between EMS and NFRS units, both while training and during actual rescue action.

American experience led to the publication of Model Uniform Core Criteria for Mass Casualty Incident Triage (MUCC) guidelines in December 2017. These are the criteria which have to be met by any medical segregation system to be used during a mass casualty incident. Among the 24 criteria, there are requirements for the triage system to be: effective regardless of patient's age and the mechanism of injury, easy to memorize, adaptable to variable conditions and leading to assigning casualty to one of 5 priority categories [5].

These criteria are met by the SALT system. It is by far more versatile than START / Jump-START system. On the other hand it leaves much space for the individual decision about the patient's chance of survival made by the rescuer. Such decision is frequently to be made rapidly and in adverse conditions. This makes medical background and experience seem necessary, which in Polish system makes SALT of no use for rescuers of the qualified first aid level. The main difficulty results from the introduction of the fifth category (not present in START system)
- the expectant casualty, marked by the gray color band. This is a category for the individuals with vital functions present, but still assessed by the rescuer as impossible to save within given conditions at current level of rescue action.

During the qualified first aid course it takes 24 hours to teach skills useful during the mass casualty incident $(2 \mathrm{~h}-$ shock, $2 \mathrm{~h}$ - proceeding with an unconscious person, $11 \mathrm{~h}$ - mechanical trauma, $3 \mathrm{~h}$ - thermal trauma, $6 \mathrm{~h}$ - mass casualty incident action tactics) [6]. By the rule, first aid training does not cover the subject of incidents with large number of victims.

\section{THE AIM}

The aim of the research is to create a simple triage tool based on basic life support and first aid rules in order to increase casualty survival rate within the initial minutes following the incident.

\section{MATERIAL AND METHODS}

During research, current first aid proceedings have been systematized, which led to creation of mass casualty incident algorithm. The analysis was based on the subject matter literature, legal acts and regulations, statistical data and author's personal experience. The idea is inspired by the concept of employing witnesses, by the algorithm proposed by the British charity organization CitizenAID [7] and by European Resuscitation Council guidelines.

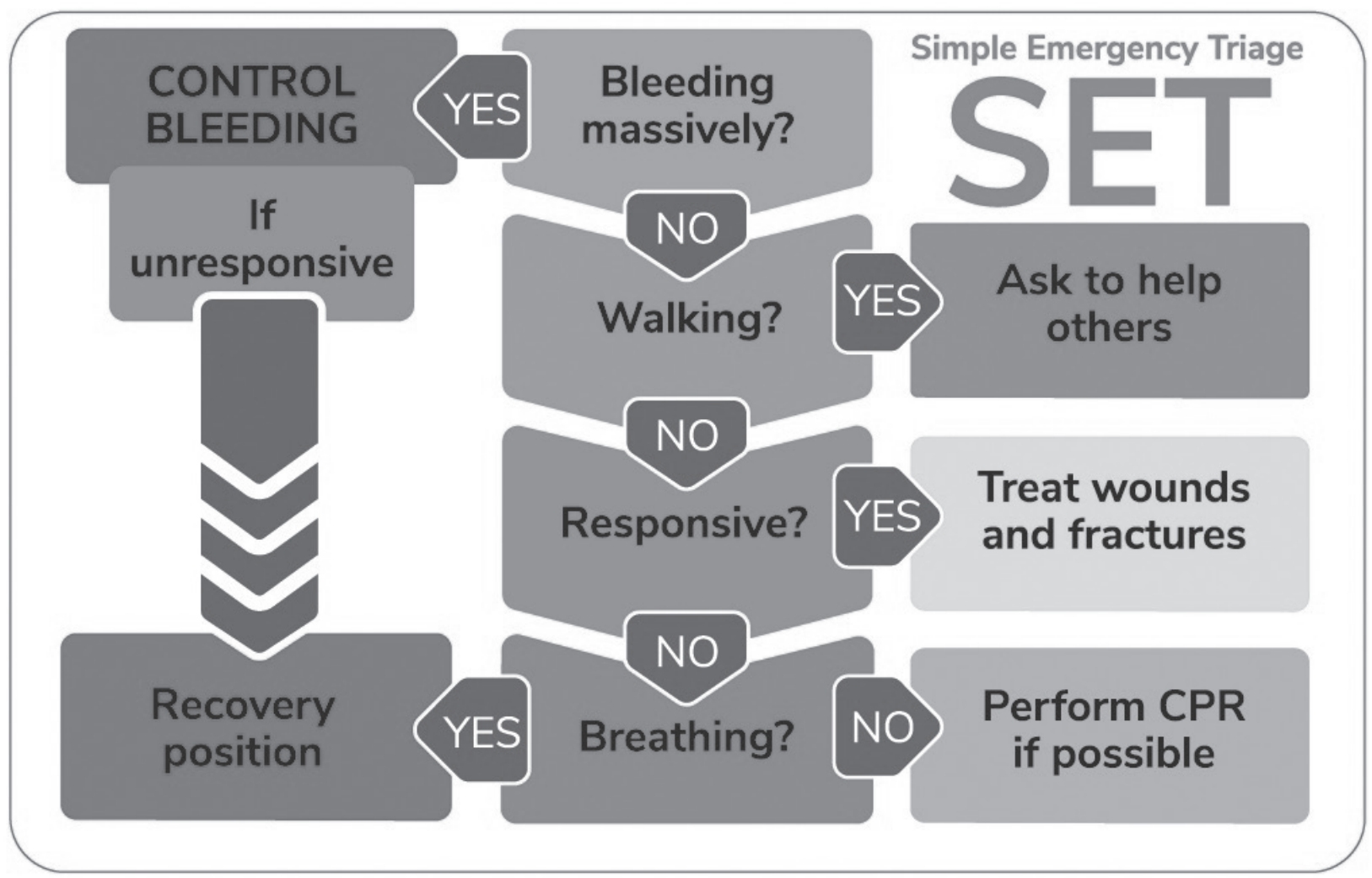

Fig. 1. Simple Emergency Triage (SET) algorithm. 


\section{RESULTS}

Regardless of triage system used by the emergency services, many simple procedures making further segregation easier and increasing survival chance may be implemented by the witnesses. In order to fully use their potential, authors have created the Simple Emergency Triage (SET) algorithm (Fig. 1). Elements of the SET system do not exceed first aid skills, which is a significant advantage compared to the abovementioned systems. The SET algorithm may turn out priceless for people with no medical background, who will find themselves on the scene of an incident with many casualties. No specialist equipment is needed, and implementing the algorithm does not influence further proceedings of the emergency services. On the first aid level the algorithm is to be treated as a systematized way of stopping the process of dying. There is no need to physically mark the casualties with the use of colorcoded bands.

\section{DISCUSSION}

Before initiating the use of Simple Emergency Triage algorithm is necessary to check for safety. It is of crucial importance in case of mass casualty incident resulting from terrorist attack, the presence of firearms, hazardous substance or other environmental danger.

SET system elements are the following:

- Bleeding control - massive blood loss is among most frequent causes of traumatic death. In the US hemorrhage is the leading death cause of Americans from one to 46 years of age [8]. Tourniquets may prevent exsanguination in the civilian setting for patients suffering either blunt or penetrating trauma to the extremity [9]. After the Boston Marathon bombing on April 15th, 2013 hospitals admitted 29 victims with amputations or severe extremity injuries. 27 of those had had the tourniquets applied (none of which was a factory tourniquet, all were improvised solutions). All 27 victims survived the incident, and only every third tourniquet is known to have been applied by the medical personnel or emergency services [10]. SET algorithm recommends controlling bleeding in any effective manner. In case of broad injuries or the lack of possibility to localize the wound clearly it is advised to place the tourniquet proximally. In any case seizure of bleeding confirms proper application. MUCC guidelines define critical interventions as the ones executable in under one minute and not requiring staying by the victim [5]. On the level of implementing the
SET algorithm it is justified to use the assistance of anyone available in applying direct pressure until an improvised tourniquet is placed or the emergency services arrive.

- Recovery position - unconscious victims (after controlling bleeding if necessary) need to be placed in a position securing airway patency. People trained in first aid should understand this by using the traditional recovery position. Potential spinal injury may make it justified to consider the H.A.I.N.E.S. (High Arm IN Endangered Spine) position. The technique of rolling the victim's head over the arm stretched upwards, which limits the uncontrolled movement of the cervical spine. According to the European Resuscitation Council guidelines, the advantages of using the H.A.I.N.E.S. position are not significant enough to recommend its use [11], while the American Heart Association guidelines do not consider restraining cervical spine motion an element necessary for first aid training [9]. In case of sufficient number of rescuers or lack of possibility to use lateral position it is advised to manually support airway patency, without moving the casualty.

- Cardiopulmonary resuscitation - while assessing breathing it is crucial to focus mainly on chest movement, as it is the most clear indication especially within the chaos of mass casualty incident. It is advised to perform cardiopulmonary resuscitation (CPR). Incident witnesses are not a part of forces and resources at direct and formal disposal of emergency services. They may therefore perform CPR even for patients classified as expectant by the services, as long as it is safe. If emergency services quickly turn out to be sufficient, there is a chance of resuscitation effort being taken over.

- Treating other wounds and injuries - if there is sufficient number of witnesses, they can treat potential causes of death other than bleeding or airway patency pathology. It is worth mentioning that current ERC guidelines recommend leaving the open chest pneumothorax without sealing dressing [11]. In case of mass casualty incident this allows for saving time and assisting further victims, while minimizing the risk of tension pneumothorax onset (which may lead to patient's condition deterioration after applying chest seal) [12].

The SET algorithm proposed may increase the survival rate of mass casualty victims. This may also make it easier for emergency services to perform professional medical segregation, as they will find some casualties already treated in terms of critical 
interventions. The SET algorithm is also a simple, coherent and clear answer for frequent question - "How should first aid be administered when there are more than one accident victim?"

\section{CONCLUSIONS}

The character of modern era mass casualty incidents taking place in densely populated city centers brings many people on scene, who are capable of administering aid in an organized manner. First aid requires the introduction of a simple tool assisting making decisions based on priorities and systematizing helping large number of victims. Simple Emergency Triage (SET) is a concept of such algorithm. In authors' opinion SET algorithm should be integral part of elementary first aid course. Field for further consideration and research is the use of this system on the qualified first aid level.

\section{REFERENCES}

1. Ustawa z dnia 8 września 2006r. o Państwowym Ratownictwie Medycznym (Dziennik Ustaw 2006 Nr 191, poz. 1410).

2. Zasady organizacji ratownictwa medycznego w Krajowym Systemie Ratowniczo-Gaśniczym. Warszawa, 2013.

3. Owens K. EMS Triage: Sorting Through the Maze. Fire Engineer. 2008;161(3).

4. Zalecenia konsultanta krajowego w dziedzinie medycyny ratunkowej dotyczące procedur postępowania na wypadek wystąpienia zdarzenia mnogiego/masowego. Warszawa, 2015.

5. Model Uniform Core Criteria for Mass Casualty Incident Triage: Addendum to the Paramedic Instructional Guidelines, U.S. Department of Transportation, National Highway Traffic Safety Administration, 2017.

6. Rozporządzenie Ministra Zdrowia z dnia 19 marca 2007r. w sprawie kursu w zakresie kwalifikowanej pierwszej pomocy (Dziennik Ustaw Nr 60, poz. 408)

7. CitizenAID - A UK Charity Empowering the Public to Save Lives official webpage. [http://www.citizenaid. org. Access on 14.10.2019].

8. Dorlac WC, DeBakey ME, Holcomb JB, et al. Mortality from isolated civilian penetrating injury. J Trauma 2005;59(1).

9. Singletary EM, Charlton NP, Epstein JL, et al. 2015 American Heart Association and American Red Cross Guidelines Update for First Aid. Circulation 2015 Nov 3; 132 (18 Suppl 2):S574-89.

10. King DR, Larentzakis A, Ramly EP, et al. Tourniquet use at the Boston Marathon bombing: Lost in translation. J Trauma Acute Care Surg. 2015;78(3).

11. Zideman DA, De Buck EDJ, Singletary EM, et al. European Resuscitation Council Guidelines for Resuscitation 2015 Section 9: First Aid.

12. Ayling J. An open question. Emerg Med Serv. 2004;33(1) .

\section{ORCID AND CONTRIBUTIONSHIP *}

Jerzy Jaskuła - 0000-0001-9160-3955 A, B, C, D, E, F

Marek Siuta - 0000-0001-5441-5429 B, C, D, E

\section{CONFLICT OF INTEREST}

Authors declare no conflict of interest.

\section{ADDRESS FOR CORRESPONDENCE}

Zakład Dydaktyki Medycznej UJ CM, ul. Św. Łazarza 16, 31-530 Kraków, Poland e-mail: jerzy.jaskula@uj.edu.pl 